\title{
UJI CEMARAN MIKROBA AIR MINUM ISI ULANG DARI DEPOT AIR MINUM DI WILAYAH KABUPATEN PONOROGO
}

\author{
Endang Ernawaningtyas ${ }^{1}$, Yaya Sulthon Aziz ${ }^{2}$, Qoirul Adi Styawan ${ }^{3}$ \\ ${ }^{1,2)}$ Akafarma Sunan Giri Ponorogo, Jl. Batoro Katong 32 Ponorogo \\ e-mail: endang.akafarma@gmail.com ${ }^{1)}$ 2) aptgolong@gmail.com \\ ${ }^{3)}$ qoiruladi14@gmail.com
}

\begin{abstract}
Abstrak
Latar belakang: Air minum isi ulang banyak digunakan oleh masyarakat Kecamatan Ponorogo untuk konsumsi rumah tangga dan juga untuk berjualan. Air minum isi ulang ini belum tentu aman untuk dikonsumsi dan terdapat bakteri, salah satunya bakteri Eschericia coli. Bakteri ini bisa menyebabkan berbagai penyakit seperti diare dan mual. Tujuan: Untuk mengetahui jumlah Angka Lempeng Total (ALT) dan Most Probable Number (MPN) Eschericia coli pada air minum isi ulang di Kecamatan Ponorogo Kabupaten Ponorogo memenuhi syarat SNI 01-3553-2006. Metode: Air minum isi ulang di Kecamatan Ponorogo akan di Uji Angka Lempeng Total dan Uji Most Probable Number Eschericia coli dengan teknik sampling purposive. Hasil: hasil uji Angka Lempeng Total (ALT) pada sampel A, B, C, D, dan E > $300 \mathrm{koloni} / \mathrm{ml}$ dan uji Most Probable Number (MPN) Eschericia coli sampel A 120 $\mathrm{MPN} / \mathrm{ml}$, sampel B $39 \mathrm{MPN} / \mathrm{ml}$, sampel C $43 \mathrm{MPN} / \mathrm{ml}$, sampel D $150 \mathrm{MPN} / \mathrm{ml}$, dan sampel E 28 MPN/ml. Simpulan dan saran: hasil Uji Angka Lempeng Total dan Uji Most Probable Number (MPN) Eschericia coli pada air minum isi ulang di wilayah Kecamatan Ponorogo Kabupaten Ponorogo tidak memenuhi persyaratan SNI 01-3553-2006.
\end{abstract}

Kata kunci: Air Minum Isi Ulang, ALT, MPN.

\begin{abstract}
Abstrack
Background: Refilled drinking water is widely used by the people of the Ponorogo District for household consumption and also for selling. Refill drinking water is not necessarily safe for consumption and contains bacteria, one of which is the Escherichia coli bacteria. These bacteria can cause various diseases such as diarrhea and nausea. Method: Refill drinking water in Ponorogo District will be tested for total plate count and Escherichia coli Most Probable Number test using purposive sampling technique. Objective: To find out the total plate count (ALT) and the most probable number (MPN) for Eschericia coli in refill drinking water in Ponorogo District, Ponorogo Regency, which meet the SNI 01-3553-2006 requirements. Results: Total Plate Number (ALT) test results in samples $A, B, C, D$, and $E>300$ colonies / $m l$ and the Most Probable Number (MPN) test of Eschericia coli sample A $120 \mathrm{MPN} / \mathrm{ml}$, sample B $39 \mathrm{MPN} / \mathrm{ml}$, sample C $43 \mathrm{MPN} / \mathrm{ml}$, sample D $150 \mathrm{MPN} / \mathrm{ml}$, and sample E $28 \mathrm{MPN} / \mathrm{ml}$. Conclusions and suggestions: the results of the Total Plate Number Test and the Most Probable Number (MPN) Test for Eschericia coli in refill drinking water in the Ponorogo District, Ponorogo Regency, do not meet the SNI 01-3553-2006 requirements.
\end{abstract}

Keywords: Refill Drinking Water, ALT, MPN.

\section{PENDAHULUAN}

Air merupakan materi yang sangat penting dalam kehidupan, baik untuk tanaman, hewan, dan manusia. Tumbuhan, hewan, dan manusia sebagian besar tersusun oleh air. Sel tumbuhan mengandung lebih dari 75\% air dan sel hewan mengandung lebih dari 67\% air (Sisca, 2016). Kadar air di dalam tubuh manusia mencapai $68 \%$ dan untuk tetap hidup kadar air dalam tubuh harus 


\section{Jurnal MEDFARM: Farmasi dan Kesehatan}

Vol. 9, No.1, Januari 2020, hal 8-12

e-ISSN : 2715-9957

dipertahankan. Kebutuhan air minum dalam manusia berfariasi mulai dari 2,1 liter hingga 2,8 liter perhari. Tergantung berat badan dan aktivitasnya (Rahayu dan Gumilar, 2017). Seiring berkembangnya teknologi masyarakat cenderung memilih cara yang praktis dengan biaya relatif murah untuk memenuhi kebutuhan air minum terutama di kota Ponorogo. Salah satu untuk memenuhi kebutuhan air minum tersebut dengan cara membeli air minum isi ulang. Depot air minum isi ulang adalah usaha industri yang melakukan proses pengolahan air baku menjadi air minum dan menjual langsung kepada konsumen. Masalah utama yang harus dihadapi dalam pengolahan air adalah semakin tingginya tingkat pencemaran air, baik pencemaran dari air limbah rumah tangga maupun limbah dari industri sehingga harus dilakukan upaya-upaya baru terus untuk mendapatkan sumber air minum, khususnya untuk pemenuhan untuk air minum yang memenuhi persyaratan yang telah ditetapkan. Salah satu penyakit yang disebabkan oleh air minum yang kualitas uji mikrobanya buruk yaitu diare (Radji et al, 2008).

Menurut Peraturan Mentri Kesehatan Nomor 492/MENKES/PER/IV/2010, persyaratan kualiltas air minum wajib memenuhi persyaratan fisika, kimiawi, mikrobiologis, dan radioaktif. Dalam SNI No.01-3553-2006, air minum dalam kemasan selain tidak boleh mengandung bakteri patogen yaitu Salmonella dan Pseudomonas aeruginosa, juga tidak boleh mengandung cemaran mikroba lebih besar dari $<2$ koloni/100ml. Sejauh ini pengusaha depot air minum isi ulang masih ada yang belum memenuhi kualitas mikrobiologis, kimia, maupun secara fisika. Kualitas air yang belum memenuhi kemungkinan syarat disebabkan kurangnya pengusaha dalam memelihara alat produksi secara rutin (Pradana, 2013). Berdasarkakan uraian di atas, perlu dilakukan penelitian untuk mengetahui bahwa air minum isi ulang di kota Ponorogo layak dikonsumsi atau tidak dan untuk mengetahui jumlah cemaran mikroba dalam sampel air isi ulang dengan menggunakan metode Angka Lempeng Total (ALT) dan Most Probable Number (MPN) Eschericia coli.

\section{METODOLOGI PENELITIAN}

A. Angka Lempeng Total (ALT) atau Total Plate Count (TPC)

Diambil $10 \mathrm{ml}$ sampel dimasukkan Erlenmeyer dan tambahkan $90 \mathrm{ml}$ pepton cair $0,1 \%$ (pengenceran $10^{-1}$ ). Pipet $1 \mathrm{ml}$ sampel dari pengenceran $10^{1}$, kemudian masukkan tabung reaksi dan tambahkan $9 \mathrm{ml}$ pepton cair $0,1 \%$ (pengenceran $10^{2}$ ). Masing-masing pengenceran dipipet 1 ml kemudian dimasukkan cawan petri dan di tambah $15 \mathrm{ml}$ media Nutrien Agar. Goyangkan cawan petri agar rata dan diamkan sampai media memadat. Setelah memadat, balik cawan petri dan bungkus masing-masing cawan petri dengan kertas koran. Inkubasi pada inkubator dengan suhu $35-37^{\circ} \mathrm{C}$ selama $24-48$ jam. Jumlah koloni bakteri yang tumbuh diamati dan dihitung. Masing-masing pengenceran dilakukan duplo. 


\section{B. Angka Paling Mungkin (APM) / Most Probable Number (MPN)}

1) Uji penduga

Disiapkan $10 \mathrm{ml}$ media Lactose Broth dalam 9 tabung reaksi yang di dalamnya terdapat tabung durham terbalik. Dimasukkan sampel ke dalam 9 tabung dan pengisian ini dibagi menjadi 3 kelompok. Kelompok I, 3 tabung berisi $10 \mathrm{ml} \mathrm{LB}$ ditambah $10 \mathrm{ml}$ sampel. Kelompok II, 3 tabung berisi $5 \mathrm{ml} \mathrm{LB}$ ditambah $1 \mathrm{ml}$ sampel. Kelompok III, 3 tabung berisi 5 $\mathrm{ml}$ LB ditambah $0,1 \mathrm{ml}$ sampel. Kemudian diinkubasi dengan suhu $35-37^{\circ} \mathrm{C}$ selama $48 \mathrm{jam}$. Amati perubahan warna biakan yang menjadi keruh dan adanya gas yang berbentuk dalam tabung durham.

2) Uji penguat

Dari uji positif dari ujia penduga diambil 1 ose bulat untuk diinokulasi ke dalam $8 \mathrm{ml}$ Brilliant Green Lactose Bile Broth (BGLBB) pada tabung reraksi yang di dalamnya terdapat tabung durham terbalik. Diinkubasi pada suhu $44^{\circ} \mathrm{C}$ selama $24-48$ jam. Diamati apakah terbentuk gas atau tidak dan cocokkan dengan tabel MPN Eschericia coli. Dari biakan yang menghasilkan gas, diinokulasi pada media Endo Agar (EA) dengan metode gores. Diinkubasi pada suhu $35-37^{\circ} \mathrm{C}$ selama $24 \mathrm{jam}$. Bila pada Endo Agar terdapat tumbuh koloni khas Eschericia coli (kilap logam warna merah). Diinokulasikan pada media agar miring, media ini diinokulasi pada suhu $37^{\circ} \mathrm{C}$ selama 24 jam.

3) Pengecatan gram

Membuat preparat smear 1 jarum ose dari uji penguat yang positif Eschericia coli secara aseptis, kemudian dikering udarakan dan difiksasi dengan nyala api spirtus. Tambahkan 2-3 tetes gram A sampai menutup noda preparat dan diamkan 3 menit. Kemudian cuci dengan air mengalir, kemudian tetesi dengan gram B, yaitu larutan mordan dan biarkan selama 30 detik. Setelah itu, cuci dengan air mengalir kemudian tetesi gram C dan biarkan selama 30 detik, cuci preparat dengan air mengalir. Tetesi preparat cat penutup yaitu gram D selama 2-3 menit kemudian cuci dengan air mengalir dan kering udarakan. Amati dibawah mikroskop.

4) Uji pelengkap

Dari pertumbuhan koloni pada media NA, dilakukan uji biokimia yang meliputi:

a. Uji Indol pada media SIM

Diambil bakteri dari NA dan diinokulasi secara tusukan dengan jarum ose. Inkubasi selama 24 jam pada suhu $37^{\circ} \mathrm{C}$. Tambahkan beberapa reagen erlich A dan B. Uji indol positif jika permukaan media berwarna merah setelah penambahan erlich.

b. Uji pembentukan asam pada media Methyl Red-Voges Proskauer (MR-VP) 
Diambil bakteri dari NA dan diinokulasikan secara aduk pada media MR-VP. Diinkubasi selama 24 jam pada suhu $37^{\circ} \mathrm{C}$. Uji pembentukan asam positif bila larutan media menjadi merah.

c. Uji pembentukan aceton pada media Methyl Red-Voges Proskauer (MR-VP)

Diambil bakteri dari media NA dan diinokulasikan secara aduk dengan jarum ose pada media MR-VP. Diinkubasi selama 24 jam pada suhu $37^{\circ} \mathrm{C}$. Ditambahkan 2-3 tetes larutan $\mathrm{KOH} 40 \%$ disertai pengocokan yang kuat. Ditambahkan 2-3 tetes reagen barit. Uji pembentukan positif jika larutan berwarna merah.

d. Uji citrate sebagai sumber karbon tunggal pada media citrate

Diambil koloni bakteri dari media NA, diinokulasikan secara goresan pada media citrate dengan jarum ose. Diinkubasi selama 24 jam dengan suhu $37^{\circ} \mathrm{C}$. Uji citrate positif bila lereng media berwarna biru.

\section{HASIL DAN PEMBAHASAN}

Analisa Data Angka Lempeng Total (ALT)

Tabel 1. Hasil Uji Angka Lempeng Total (ALT)

\begin{tabular}{cccc}
\hline Sampel & Persyaratan & Hasil Pengujian & Ket \\
\hline A & & $>300$ & TMS \\
B & & $>300$ & TMS \\
C & Maks. $1,0 \times 10^{2}$ & $>300$ & TMS \\
D & & $>300$ & TMS \\
E & & $>300$ & TMS \\
\hline
\end{tabular}

Analisa Data Most Probable Number (MPN)

Tabel 2. Hasil Uji Angka Lempeng Total (ALT)

\begin{tabular}{ccccc}
\hline \multirow{2}{*}{ Sampel } & \multicolumn{3}{c}{ Hasil pengamatan } & MPN/ml \\
& @ $10 \mathrm{ml}$ & @ $1 \mathrm{ml}$ & @ $0,1 \mathrm{ml}$ & \\
\hline A & 3 & 1 & 2 & 120 \\
B & 3 & 0 & 1 & 39 \\
C & 3 & 1 & 0 & 43 \\
D & 3 & 2 & 1 & 150 \\
E & 2 & 2 & 1 & 28 \\
\hline
\end{tabular}

Dari hasil penelitian ini didapat hasil Angka Lempeng Total sampel A >300 koloni/ml, artinya adalah setiap gram atau milimeter sampel A terdapat $>300$ koloni bakteri. Sampel B >300 koloni/ml, artinya adalah setiap gram atau milimeter sampel B terdapat $>300$ koloni bakteri. Sampel C $>300 \mathrm{koloni} / \mathrm{ml}$, artinya adalah setiap gram atau milimeter sampel $\mathrm{C}$ terdapat $>300$ koloni bakteri. Sampel D >300 koloni/ml, artinya adalah setiap gram atau milimeter sampel D terdapat $>300$ koloni bakteri. Dan Sampel E >300 koloni/ml, artinya adalah setiap gram atau milimeter sampel E terdapat 


\section{Jurnal MEDFARM: Farmasi dan Kesehatan}

Vol. 9, No.1, Januari 2020, hal 8-12

e-ISSN : 2715-9957

>300 koloni bakteri. Hal itu dibuktikan dengan adanya pengujian cawan dimana sampel dimasukkan ke dalam cawan petri yang sudah diberi media Natrium Agar (NA) sebagai tempat pertumbuhan bakteri. Menurut Batas Cemaran Mikroba Air Minum Dalam Kemasan (AMDK) SNI 01-3553-2006 semua sampel air minum isi ulang tidak memenuhi persyaratan, karena jumlah koloni lebih dari 1,0 $\mathrm{x}$ $10^{2} \mathrm{koloni} / \mathrm{ml}$. Untuk hasil pengamatan Most Probable Number (MPN) Escherichia coli didapatkan hasil sampel A $120 \mathrm{MPN} / \mathrm{ml}$, artinya terdapat 120 koloni bakteri pada setiap gram atau setiap milliliter sampel A. Sampel B $39 \mathrm{MPN} / \mathrm{ml}$, artinya terdapat 39 koloni bakteri pada setiap gram atau setiap milliliter sampel B. Sampel C $43 \mathrm{MPN} / \mathrm{ml}$, artinya terdapat 43 koloni bakteri pada setiap gram atau setiap milliliter sampel C. Sampel D $150 \mathrm{MPN} / \mathrm{ml}$, artinya terdapat 150 koloni bakteri pada setiap gram atau setiap milliliter sampel D. Sampel E $28 \mathrm{MPN} / \mathrm{ml}$, artinya terdapat 28 koloni bakteri pada setiap gram atau setiap milliliter sampel E. Hal tersebut dibuktikan dengan hasil pada uji penduga dan uji penguat yang menghasilkan gelembung gas pada setiap tabung. Lalu tabung yang positif dari setiap sampel dicocokkan dengan tabel MPN. Menurut persyaratan SNI 01-3553-2006, nilai Most Probable Number air minum isi ulang tidak memenuhi syarat karena jumlah koloni lebih besar dari persyaratan, yaitu $>2 \mathrm{koloni} / \mathrm{ml}$.

Sampel yang tidak memenuhi persyaratan Angka Lempeng Total (ALT) dan Most Probable Number (MPN) kemungkinan terjadi karena pengolahan air minum di depot yang tidak sesuai dengan protap, penyimpanan yang belum standar, wadah bahan baku yang tidak terbuat dari tara, pengisian air yang tidak steril, pencucian wadah yang kurang bersih, dsb.

Lingkungan yang jelek dan tempat yang kotor dapat meningkatkan jumlah bakteri yang sangat tinggi dan menimbulkan penyakit. Penularan penyakit terjadi melalui air yang terkontaminasi bakteri patogen dan di salurkan kepada manusia melalui mulut. Penyakit umum yang di alami adalah diare, sakit perut, tifus, paratifus, disentri, dsb yang disebabkan oleh adanya pencemaran bakteri Eschericia coli, Salmonella, Shigella dan Vibrio pada air.

\section{KESIMPULAN}

Uji Angka Lempeng Total (ALT) pada air minum isi ulang di wilayah Kecamatan Ponorogo Kabupaten Ponorogo tidak memenuhi persyaratan SNI 01-3553-2006 dan Uji Most Probable Number (MPN) Eschericia coli tidak memenuhi persyaratan SNI 01-3553-2006.

\section{Daftar pustaka}

KEMENDIKBUD RI, Buku Mikrobiologi Kurikulum 2013.

Pradana et al .(2013). Uji Kualitas Air Minum Isi Ulang di Kecamatan Sukodono, Sidoarjo Ditinjau Dari Perilaku dan Pemeliharaan Alat. Jurnal Teknik ITS 2.2.

Radji M. 2010. Buku Ajar Mikrobiologi Panduan Mahasiswa Farmasi dan Kedokteran. Jakarta. EGC. 
Jurnal MEDFARM: Farmasi dan Kesehatan

Vol. 9, No.1, Januari 2020, hal 8-12

e-ISSN : 2715-9957

Rahayu S.A dan Gumilar M.H .(2017). Uji cemaran air minum masyarakat sekitar Margahayu Raya

Bandung dengan identifikasi bakteri Escherichia coli. Indonesian Journal of Pharmaceutical Science and Technology 4.2.

Sisca, V .(2016). Penentuan Kualitas Air Minum Isi Ulang Terhadap Kandungan Nitrat, Besi, Mangan, Kekeruhan, pH, Bakteri E. Coli dan Coliform. Chempublish Journal 1.2. 